\title{
The meanings of death and dying: the perspective of crack users
}

\author{
Fernando José Guedes da Silva Júnior ${ }^{1}$ \\ Claudete Ferreira de Souza Monteiro ${ }^{2}$
}

\begin{abstract}
The consumption of crack can constitute in an inauthentic form of the existence that leads a person to live improperly the being-toward-death. Given this reality, this study aimed to comprehend the significance of death and dying for the user of crack and to unveil the meanings attributed to this significance. This qualitative study was conducted, based on the phenomenological method, with 12 crack users, in the therapeutic process, in a Psychosocial Care Center - Alcohol and Drugs (CAPSad), in the period from February to April 2011, in Teresina, Piauí. The results show that death is signified, ontically, as a companion, a partner, a passage, a journey and as the crack itself. It was concluded that this significance expressed an inauthentic experience, directed toward the incessant interaction with crack, accompanied by a feeling of nullity and relational disengagement.
\end{abstract}

Descriptors: Death; Crack Cocaine; Nursing.

\footnotetext{
${ }^{1}$ Master's student, Departamento de Enfermagem, Universidade Federal do Piauí, Brazil. Professor, Faculdade de Educação São Francisco, Brazil.

2 PhD, Professor, Faculdade de Saúde, Ciências Humanas e Tecnológicas do Piauí, Brazil. Adjunct Professor, Centro de Ciências da Saúde, Universidade Federal do Piauí, Brazil.
}

Corresponding Author:

Fernando José Guedes da Silva Júnior Universidade Federal do Piauí

Campus Universitário Ministro Petrônio Portella

Bairro: Ininga

CEP: 64049-550, Teresina, PI, Brasil

E-mail: fernandoguedesjr@gmail.com 


\section{Os significados da morte e do morrer: a perspectiva de usuários de crack}

O consumo de crack pode constituir-se em forma inautêntica da existência que leva a pessoa a viver de forma imprópria o ser-para-a-morte. Diante dessa realidade, objetivou-se compreender o significado da morte e do morrer para o usuário de crack e desvelar os sentidos atribuídos a esses significados. Realizou-se pesquisa qualitativa, fundamentada no método fenomenológico, com 12 usuários de crack, em processo terapêutico, em um Centro de Atenção Psicossocial - Álcool e Drogas (CAPSad), no período de fevereiro a abril de 2011, em Teresina, Piauí. Os resultados mostram que a morte é significada, onticamente, por companheira, parceira, passagem, viagem e pelo próprio crack. Conclui-se que esse significado expressa uma vivência inautêntica, direcionada ao convívio incessante do crack, acompanhada por sentimento de nulidade e descompromisso relacional.

Descritores: Morte; Cocaína Crack; Enfermagem.

\section{Los significados de la muerte y el morir: la perspectiva de los consumidores de crack}

El consumo de cocaína puede estar en un modo auténtico de la existencia que lleva la persona a vivir mal ser-para-la-muerte. Ante esta realidad se tuvo como objetivo comprender el significado de la muerte y el morir para los consumidores del crack revelar los significados atribuidos a estos significados. Se realizó un estudio cualitativo sobre el método fenomenológico con 12 usuarios de crack en el proceso terapéutico en un Centro de Atención Psicosocial de alcohol y otras drogas en el período de febrero a abril de 2011 en Teresina, Piauí. Los resultados muestran que la muerte se entiende, onticamente por socio, asociación, entradas, viajes y el propio crack. Se concluye que el sentido es expresado en una experiencia inauténtica dirigido a la convivencia de la grieta incesante acompañada por un sentimiento de la nada y la retirada relacional.

Descriptores: Muerte; Cocaina Crack; Enfermería.

\section{Introduction}

The consumption of substances has marked the history of civilization. At first, some of these alternatives (teas, magic smoke, medicinal oils and others) were employed in a restrained way, often in rituals, with a curative and/or ritualistic design, as well as in order to lessen the anguish and suffering. Over the centuries there has been a distortion of this purpose, with these substances becoming used in orderto increase the pleasure of the user, exacerbating the consumption beyond the curative/medicinal borders. It is also noteworthy that this consumption was articulated to the marketological view of the substances, which contributed decisively to the growth of supply, valorization and expansion of the consumption. In this context, the access of man to the vehicles of inebriation that distort perception and mood was expanded, with the consequence, most of the time, of behavioral alterations. In line with this reality, these vehicles were characterized as licit and illicit substances. In recent decades, the consumption of illicit drugs has increased from quantities considered irrelevant to global scale production and distribution, as a commercial product that, besides being prohibited, is controlled by large smuggling cartels. The results of this expansion cause social, economic and health disorders, making it a serious judicial and public health problem ${ }^{(1-2)}$.

Among the most widely abusively consumed illicit substances in the world, cocaine, heroin and cannabis stand out. The more relevant, as a public health problem, is cocaine, characterized by more intense harm, the consumption of which was exacerbated from 1987, 
mainly in the form of rocks: crack $^{(3-4)}$. It is estimated that crack is consumed by $0.3 \%$ of the global population and that the majority of users, about $70 \%$, are concentrated in the Americas ${ }^{(5)}$. In Brazil, its use has reached $0.7 \%$ of the general population, becoming one of the most widely used illicit substances, overtaken only by marijuana $(8.8 \%)$ solvents $(6.1 \%)$ and cocaine $(2.3 \%)^{(6-8)}$. The consumption of crack has widened significantly and at an alarming rate since it was first conceived. Therefore, it is necessary to emphasize that the instant euphoria triggered by the consumption of this drug strengthens and motivates, for the majority of individuals, the desire for a new episode of consumption, establishing an intimate and almost irrepressible relationship of dependency between the subject and drug. Although they feel and know the consequences, crack users overcome any obstacle, turning increasingly to the "rock bottom" in an uncontrolled attempt to survive by means of the drug. This fact leads to the question: would this drug be a quotidian death?

It can be speculated that in the phenomenon of drug dependency lies the deprivation of the value of life and the lack of a real and significant existential meaning. The crack user belongs to no one and nothing, however, in the quest to survive through the drug, he dies every day. Death is a way of being, that the presence assumes at the moment in which it is ${ }^{(9)}$. The crack dependent person, given the quotidian difficulties, finds in this drug a supposedly effective path to overcome their weakness and prevent the disintegration of their ego. For this reason, the development and implementation of effective coping measures is configured as an arduous task. Conversely, Nursing, as a science of care, deals in its quotidian work with increasingly young people, whether men or women, who engage in this daily dying through crack use. To seek, therefore, to comprehend how these choices are made and these decisions are taken, will contribute to the broader view of the mode of action of these individuals and perhaps be a starting point for the initiation of a client-centered therapeutic approach. Thus, it is necessary to enter into the subjective world of these users, to know what connections they make to leave behind laws, families, feelings, and to dedicate themselves to live with and for the drug.

To construct this knowledge the proximity with the phenomenological reference has become imperative, since this allows the unveiling of meanings, the comprehension of feelings, and the revelation of what is hidden, making it possible to arrive at the essence of the phenomenon. Therefore, the aims set for this study were: to comprehend the significance of death and dying for the person using crack and to reveal the meanings attributed to this significance.

\section{Methodological framework}

A qualitative study was carried out, based on the phenomenological method. The method used was developed in three closely intertwined steps: the description, the reduction and the comprehension. The phenomenological description was the first moment in which the subject was asked to speak freely about the studied phenomenon in their world-life. The second moment was constituted as the phenomenological reduction, where it was sought to move away from all the concepts and pre-established knowledge (epoch) regarding the theme and to select parts of the description considered essential for the unveiling of the proposed aims. Finally, the phenomenological or hermeneutic comprehension was performed, where the raw expressions of the discourses were replaced by the expressions of the researcher ${ }^{(10-11)}$.

The study was conducted in a Psychosocial Care Center - Alcohol and Drugs (CAPSad), in the period from February to April 2011. The following were considered as the inclusion criteria of the subjects: to be a crack users, over 18 years of age, in the therapeutic process, and to voluntarily agree to participate in the study with the signing of the Terms of Free Prior Informed Consent. The study subjects were 12 crack users, male, aged between 18 and 45, with complete elementary education. All had followed a similar route regarding the dynamics of the drug consumption: always starting with the use of loló (a mixture of ethyl alcohol or benzene, chloroform, ether and fruit juice) and lança-perfume (a solvent), followed by the consumption of cannabis, cocaine and crack. It should be noted that the choice and number of participants in the study was unintentional. The fact that they were exclusively male, is justified, taking into consideration that, in the period for obtaining the reports, there were no women in the therapeutic process for the use of crack. The number of interviewees, in turn, was defined by the saturation of information obtained in the reports.

The aims of the study, the methodology and form of their participation were presented to the participants. Privacy for the interview was promoted, thus allowing the opportunity for a voluntary and interesting agreement, as recommended by Resolution No. 196/96 of the National Health Council. It should be highlighted 
that the principles of ethics, secrecy and confidentiality were followed. The study was approved by the Research Ethics Committee of the Faculty of Health, Human Sciences and Technology of Piauí (NOVAFAPI) under protocol CAAE No.0468.0.043.000-10.

The data were obtained using a script of open questions, mediated by the phenomenological interview with the following questions: can you comment freely about the use of crack for you? How do you relate beinga-crack-user with death and dying? These questions permitted reports to be heard regarding experiences with crack and how death is interwoven with this way of being and being-in-the-world. In this moment, the particularities of the studied clientele were considered, seeking strategies favorable for the conveyance of the description of the phenomenon according to those who experience it. The results are presented in units of meaning, grouped by the highlighted contents of the reports of the subjects and analyzed based on studies regarding the theme, supported by the concepts of phenomenological thinking of Martin Heidegger.

\section{Results and Discussion}

The reading was carefully repeated several times until it became clear, taking a significant meaning, known as "vague and median comprehension" because it is generated in the accounts of the subject. From this point, the units of meaning about death and dying for crack users were organized. As the first unit of meaning, it was possible to comprehend that, for these crack users, death and dying have meanings like companion and partner in the life. This relationship with the phenomenon is established through the daily and almost indelible conflict between living and dying. There was a direct association of the experience with the drug and death, since "people make meanings from their experiences and gain experiences from the meaning they make"(12).

Death can come at any time. It is a companion (D1).

Death walks with you all the time. It accompanies you at all times. It is a partner. It's like it is looking at you, following you, talking about you (D3).

The phenomenon in question is meant as a necessary, daily presence, which accompanies, guides and speaks; in summary indicates. Crack and death are intertwined in the quotidian lives of these users, guiding their lives, determining values, linking their existences. When, however, death is signified as a companion, a partner all the time, it is an expression of their nullity, of the non-presence, of the lack of expectation of change. This meaning reveals death as something expected, that comes "together" and "with" the drug. The vague and median comprehension also reveals death and dying as a journey and passage. This meaning produces a painful awareness and generates the most diverse feelings, such as loss, pain and sadness. For these subjects, death is comprehended as transcendence, perceived as a passage and not as an end.

Death is like a passage (D8).

A journey that I know there will be no return from, but a journey (D11).

Death is characterized by being itself, irredeemable, insurmountable, certain and undetermined. However, this can be anticipated when the man is lost in the impersonal, in the inadequacy and in the inauthenticity ${ }^{(9)}$. This meaning (journey and passage), attributed to death and dying, is assumed by the crack user as a way of living for the things and objects. Therein lies the inauthenticity, revealing that, in the quotidian of crack consumption, lies a lack of esteem for life. In the reports it is possible to see that these users are aware that death will come. They understand that it is a living presence of the movement of the human existence. They are sure of their own death, however, without them knowing the day or the hour.

Valuing death and dying as a passage and journey, rather than recognizing it as existentially free, is to live in decadence, in an inappropriate and inauthentic way, using escape as a means of avoiding anguish. It is alienating and places oneself in mediocrity ${ }^{(13)}$. People grieve exactly because they are beings with possibilities, and their existential anguish is due to the fact that, because they are mortal, they can become an impossibility. Death is the possibility of the impossibility, from which one cannot escape, however, man tries at all costs to distance himself from it.

In the second unit of meaning, the subjects referred to death not as the finitude of life, but in an undifferentiated way; something that can happen at any time, an expression of nothing.

I could die anytime. It's the only thing I know. I will die. But as crack users we will not die. We do not know what death is (D6).

When was having the "craving" I thought I was going to die all the time. A bad feeling comes. And it was greater when I used crack (D10).

The being-toward-death is the true meaning of the existence. With death there are no other projects to be performed. Finitude is the last possibility of being- 
able-to-be. When death becomes reality existence ends. Thus, death denotes fear by unveiling the possibilityof-not-being-present-anymore, as well as by showing the closure of the endless possibilities of coming-intobeing ${ }^{(9)}$. For the subjects of this study, there was no such ontological awareness of death and dying. There was no reference to the fear of the disappearance of the presence in the world, but of a walk together, one certainty is that being with crack is also being with death. Therefore, for many of these subjects, death and dying were also significant as being the crack itself. This experience indicates the presence of a space/time dimension, in which the subject loses his reference network, feels switched off, experiences the lack of connection with his place of origin, feels in orbit in the place he inhabits ${ }^{(12)}$. He cannot refer to his position, his role, in summary, his place in the world - his reference is crack.

Death is to use crack [...]. The guy using crack, he's dead. They are not dead only because they are not buried. They are out of their minds. They rob friends, parents, anyone just to smoke. For me death was being the crack itself (D3).

Death is to use crack. When I spent more than four days using I thought: this shit is killing me. We of the "ghetto" know that crack kills in four or five years. If not from health, it is from the things we do when we use (D4).

In this unit of meaning, the reports show that the consumption of crack causes the users to increasingly lose the incentive to search for their personal identity, and consequently, they are thrown into impropriety, into the inauthenticity. This comprehension can be understood by considering that crack users, when engaged in the quotidian of the consumption of drugs, are limiting themselves in the experience of their sexuality, leisure, social and working lives.

Death is the end of the career, it is when everything finishes. The end of the story. And crack has speeded up the process because it takes you, destroys your health, destroys your life cycle [...] family, friends [...] it leaves you blind, deaf, you lose the sense (D7).

With crack you do not feel tired, like eating, having a relationship, having sex. You just feel like using it. Drinking and using it. Is this life? For me this is death, this is the end. Because we do not feel like living (D12).

To signify death as being the crack itself is a comprehension of how this drug may distance the user from everyone and everything. Dying is to disappear from family, friends and work. It is to get lost in itself, it is to devalue oneself and valorize the drugs, so that in order to be with it one will lie, steal, involve family members and friends, in exchange for the greater abyss: crack. When facing death man is confronted with life. At this point, they abdicate the conventional opinions and autonomously choose how they will live, i.e. to live their own-being. In this context, living-with-crack is approaching finitude.

The being of the man is a being of possibilities, it is a being-able-to-be. The existence implies being launched in these possibilities. In this way, crack users are always faced with alternatives, before which they must always make choices. Thus, the human existence is structured in terms and possibilities and the existence is a choice between coming-into-being or ending. The choice is an experience because it is always accompanied by profound and troublesome feelings ${ }^{(12)}$. When one is in a situation of choice between alternatives it is due to a mismatch, a breakdown in what was right and defined, and thus, one feels as if suspended in the air. When in crisis, one experiences feelings of instability and anguish ${ }^{(14)}$. In the reality in which this study is situated, this is especially perceived through the familial and conjugal instability evidenced in the reports.

My family was already totally dysfunctional. With me using crack it all got worse (D1).

My children and my wife left me. After this the drug made me lose everything. My parents and my brothers (D4).

It is noteworthy that, for the analysis of the statements of the subjects of this study, it was necessary to deepen the comprehension regarding the relational dimension and the construction of the identity of the man. This relational dimension, which is the foundation of the constitution of man, "can only be in reference to another that is not himself"(12). It is therefore from this awareness of the world that he will organize his relationships, make his choices, affecting and being affected by each of these. They are comings and goings that, when small, will unite and construct the being. When, however, the obstacles, be they emotional, financial or relational, are numerous, man will seek a way to construct his identity in the initially easily offered compensation for his losses - which is the drug. "For the addict, the drug is a question of survival"(12). In this context, the relationship that the subjects of this study made between death and dying is intimately linked to their own crack use, expressing an inauthentic experience, presented by feeling of nullity, lack of relational commitment and focused on the relational symbiosis with crack. 


\section{Final considerations}

The phenomenology opens as a new concept for the comprehension of the meanings attributed to the contemporary phenomena. This methodical approach represents a constitution of the search for the being and for the meanings experienced by them. The meaning of death and dying expressed by the users of crack are ontically shown through companionship, partnership, passage, journey and as being the crack itself. In this context, it is evident that the meaning of death and dying for the crack user is a difficult and delicate object to be explored. These users, when reflecting on this phenomenon, allow themselves to be identified through words, gestures and positions in which they recognize themselves as mortal beings, although they are not prepared for the experience of the authentic meaning of the existence: being-toward-death. It is noteworthy that many of the meanings encountered in this group are also shared by others, often by the majority of the population, for example, the sense of transcendence.

From this study, mediated by Heideggerian hermeneutics, it became possible to penetrate this relational world of the crack user. They experience a duality between living and dying due to the consumption of this substance. In this context, death and dying are unveiled as transcendence, denoting a living in a decadent, inauthentic and inappropriate way, considering that this experience is part of the choice of that person in their way of being.

Despite the relevance of the contribution to the knowledge produced, the study presents limitations. One of these refers to the constitution of the sample, composed exclusively of male users, failing to present the phenomenon in the female context. The other limitation refers to the fact that these users were encountered in treatment at the time of the data collection, which could contribute to more conscious reflections. Therefore, the expansion of the study in order to involve women is suggested.

\section{References}

1. Noto AR, Baptista BC, Faria ST, Nappo AS, Galduróz JCF, Carlini EAC. Droga e saúde na empresa brasileira: uma análise de artigos publicados em jornais e revistas. Cad Saúde Pública. 2003;17(1):69-9.

2. Neves $A C L$, Miasso AI. "Uma força que atrai": o significado das drogas para usuários de uma ilha de Cabo Verde. Rev. Latino-Am. Enfermagem. 2010;18(2):159-68.
3. Ferreira OF Filho, Turchi MD, Laranjeira R, Castelo A. Perfil sociodemográfico e de padrões de uso entre dependentes de cocaína hospitalizados. Rev Saúde Pública. 2003;37(6):751-9.

4. Kessler F, Pechansky F. Uma visão psiquiátrica sobre o fenômeno do crack na atualidade. Rev Psiquiatr Rio Gd Sul. 2008;30(2):96-8.

5. Araújo RB, Pansard M, Boeira BU, Rocha NS. As estratégias de coping para o manejo da fissura de dependentes de crack. Rev HCPA. 2010;30(1):36-42.

6. Galduróz JC, Noto AR, Nappo AS, Carlini EA. Uso de drogas psicotrópicas no Brasil: pesquisa domiciliar envolvendo as 107 maiores cidades do país - 2001. Rev. Latino-Am. Enfermagem. 2005;13(nº esp):888-95.

7. Duailibi LB, Ribeiro M, Laranjeira R. Profile of cocaine and crack users in Brazil. Cad Saúde Pública. 2008;24(4):545-57.

8. Bernardy CCF, Oliveira MLF. O papel das relações familiares na iniciação ao uso de drogas de abuso por jovens institucionalizados. Rev EsC Enferm USP. 2010;44(1):11-7.

9. Heidegger M. Ser e Tempo. Tradução de Márcia Sá Cavalcante Schuback. 11th.ed. Petrópolis: Vozes; 2009. $598 \mathrm{p}$.

10. Terra MG, Silva LC, Camponogara S, Santos EKA, Souza AIJ, Erdmann AL. Na trilha da fenomenologia: um caminho para a pesquisa em enfermagem. Texto Contexto-Enferm. 2006;15(4):672-8.

11. Monteiro CFS, Rocha SS, Paz EPA, Souza IEO. Fenomenologia heideggeriana e sua possibilidade na construção de estudos de Enfermagem. Esc Anna Nery. 2006;10(2):297-301.

12. Santos JL. O duelo entre ser e ter: uma aproximação do sentido da dependência de drogas na adolescência. In: Castro DSP, Ázar FP, Piccino JD, Josgrilberg RS. Fenomenologia e análise do existir. São Paulo (SP): Sobraphe; 2000. p. 309-26.

13. Santos IPA, Giovannini RGI, Ramirez SCC, Silva ZB. A homossexualidade como modo de existência. In: Castro DSP, Ázar FP, Piccino JD, Josgrilberg RS. Fenomenologia e análise do existir. São Paulo (SP): Sobraphe; 2000. p. 327-43.

14. Piccino JD. Da alma a existência. São Paulo: Sobraphe; 1984. 135 p. 